\section{Kidney \\ Blood Pressure Research}

Kidney Blood Press Res 2012;36:119-130

\begin{tabular}{l|l}
\hline DOI: $10.1159 / 000341487$ & (c 2012 S. Karger AG, Basel \\
\hline
\end{tabular}

www.karger.com/kbr

119

Original Paper

\title{
DPP-4 Inhibition on Top of Angiotensin Receptor Blockade Offers a New Therapeutic Approach for Diabetic Nephropathy
}

\author{
Markus L. Alter ${ }^{\mathrm{a}, \mathrm{b}} \quad$ Ina M. Ott $\mathrm{t}^{\mathrm{b}, \mathrm{c}} \quad$ Karoline von Websky ${ }^{\mathrm{b}, \mathrm{c}}$ Oleg Tsuprykov ${ }^{\mathrm{b}, \mathrm{c}}$ \\ Yuliya Sharkovska ${ }^{b}$ Katharina Krause-Relle ${ }^{b, c}$ Jens Railac Andrea Henze ${ }^{c}$ \\ Thomas Klein ${ }^{d}$ Berthold Hocher ${ }^{b, c}$
}

aDepartment of Nephrology, Charité, Campus Benjamin Franklin, Berlin, Germany, ${ }^{b}$ Center for Cardiovascular Research, Charité, Campus Mitte, Berlin, Germany, 'Institute for Nutritional Science, University of Potsdam, Germany and 'Boehringer Ingelheim Pharma GmbH \& Co. KG, Biberach, Germany

\section{Key Words}

Diabetic nephropathy • DPP-4 inhibitor • Linagliptin • Renin-angiotensin system

\begin{abstract}
Background: The need for an improved treatment for diabetic nephropathy is greatest in patients who do not adequately respond to angiotensin II receptor blockers (ARBs). This study investigated the effect of the novel dipeptidyl peptidase-4 inhibitor linagliptin alone and in combination with the ARB telmisartan on the progression of diabetic nephropathy in diabetic endothelial nitric oxide synthase (eNOS) knockout mice. Methods: Sixty male eNOS knockout C57BL/6J mice were divided into four groups after receiving intraperitoneal highdose streptozotocin: telmisartan (1 mg/ $\mathrm{kg}$ ), linagliptin (3 mg/ $\mathrm{kg}$ ), linagliptin + telmisartan (3 $\mathrm{mg} / \mathrm{kg}+1 \mathrm{mg} / \mathrm{kg}$ ) and vehicle. Fourteen mice were used as non-diabetic controls. Results: After 12 weeks, urine and blood were obtained and blood pressure measured. Glucose concentrations were increased and similar in all diabetic groups. Telmisartan alone reduced systolic blood pressure by $5.9 \mathrm{mmHg}$ versus diabetic controls $(111.2 \pm 2.3 \mathrm{mmHg}$ vs $117.1 \pm$ $2.2 \mathrm{mmHg}$; mean $\pm \mathrm{SEM} ; P=0.071$ ). Combined treatment significantly reduced albuminuria compared with diabetic controls $(71.7 \pm 15.3 \mu \mathrm{g} / 24 \mathrm{~h}$ vs $170.8 \pm 34.2 \mu \mathrm{g} / 24 \mathrm{~h} ; P=0.017)$, whereas the effects of single treatment with either telmisartan $(97.8 \pm 26.4 \mu \mathrm{g} / 24 \mathrm{~h})$ or linagliptin (120.8 $\pm 37.7 \mu \mathrm{g} / 24 \mathrm{~h})$ were not statistically significant. DPP-4 inhibition, alone and in combination, led to significantly lower plasma osteopontin levels compared with telmisartan alone. Histological analysis revealed reduced glomerulosclerosis after Linagliptin alone and in combination with telmisartan in comparison to non treated diabetic animals
\end{abstract}




\section{Kidney Blood Pressure Research}

$(p<0.01$ and $p<0.05)$. Kidney malonaldehyde immune-reactivity, a marker of oxidative stress, was significantly lower in animals treated with linagliptin. Conclusions: DPP-4 inhibition on top of ARB treatment significantly reduced urinary albumin excretion and oxidative stress in diabetic eNOS knockout mice. Linagliptin on top of an angiotensin II receptor blocker may offer a new therapeutic approach for patients with diabetic nephropathy.

Copyright (C) 2012 S. Karger AG, Basel

\section{Introduction}

As the prevalence of diabetes mellitus and its complications such as diabetic nephropathy rises in western industrial nations, the severe consequences of the disease become increasingly important. Diabetic nephropathy accounts for approximately one third of all patients who require regular dialysis [1]. Although an association between hyperglycaemia and diabetic nephropathy is evident, it is unclear why some patients with diabetes develop overt nephropathy despite optimal treatment. Evidence suggests that a therapeutic approach including blockade of renin-angiotensin system (RAS) is very effective [2-5]. Telmisartan, an effective angiotensin II receptor blocker (ARB) $[6,7]$ has been shown to dosage-dependently reduce transition rates to overt nephropathy [8] and to significantly increase nitric oxide (NO) activity in the renal endothelium among patients with type 2 diabetes (T2DM) [4, 9]. Hence, the need for an improved treatment for diabetic nephropathy is greatest in patients who do not adequately respond to ARBs.

Dipeptidyl peptidase-4 (DPP-4) is a ubiquitously available serine peptidase that cleaves a number of endocrine peptides. Substrates for DPP-4 include glucagon-like peptide (GLP)-1, B-type natriuretic peptide (BNP) and stromal cell-derived factor- $1 \alpha$ (SDF-1 $\alpha$ ). Experimental models have attributed potential effects in kidneys and heart to these peptides [10-12]. The anti-diabetic action of DPP-4 blockade is mainly mediated by enhancement of the incretins gastric inhibitory polypeptide (GIP) and GLP-1 [13], both of which reduce hyperglycaemia [14]. In patients with T2DM, this strategy decreases both pre- and postprandial glucose levels as well as $\mathrm{HbA}_{1 \mathrm{c}}[15]$ without risk of hypoglycaemia $[16,17]$.

Linagliptin is a competitive DPP-4 inhibitor that is approved for the treatment of patients with T2DM. In non-clinical and clinical studies linagliptin has been shown to be a highly potent and well-tolerated drug [18-20]. In contrast to other approved DPP-4 inhibitors, renal excretion of linagliptin is low $[11,17,19]$. Therefore, linagliptin can be used in renally impaired patients without dose adjustment.

This study investigated the effect of linagliptin, alone and in combination with telmisartan, on the progression of diabetic nephropathy in diabetic endothelial nitric oxide synthase (eNOS) knockout mice, a new model closely resembling human pathology [2123]. Mice were treated with adequate dosages for 11 weeks and assessed for major renal parameters, blood glucose (BG) and blood pressure (BP).

\section{Materials and Methods}

\section{Chemicals}

Linagliptin [BI1356; 8-[(3R)-aminopiperidin-1-yl]-7-(but-2-yn-1-yl)-3-methyl-1-[(4-methyl-quinazolin-2-yl)methyl]-3,7-dihydro-1H-purine-2,6-dione] and telmisartan were developed and synthesized by Boehringer Ingelheim. Unless otherwise stated, all other reagents were of analytical grade and were purchased from Sigma-Aldrich (Seelze, Germany), Merck KGaA (Darmstadt, Germany) and Carl Roth GmbH \& Co. KG (Karlsruhe, Germany).

Study design

Mice were kept under standardized conditions with respect to temperature and humidity and were housed in a $12 \mathrm{~h}$ light/12 h dark cycle in solitary cages with food (commercial standard diet) and water ad 


\section{Kidney \\ Blood Pressure Research}

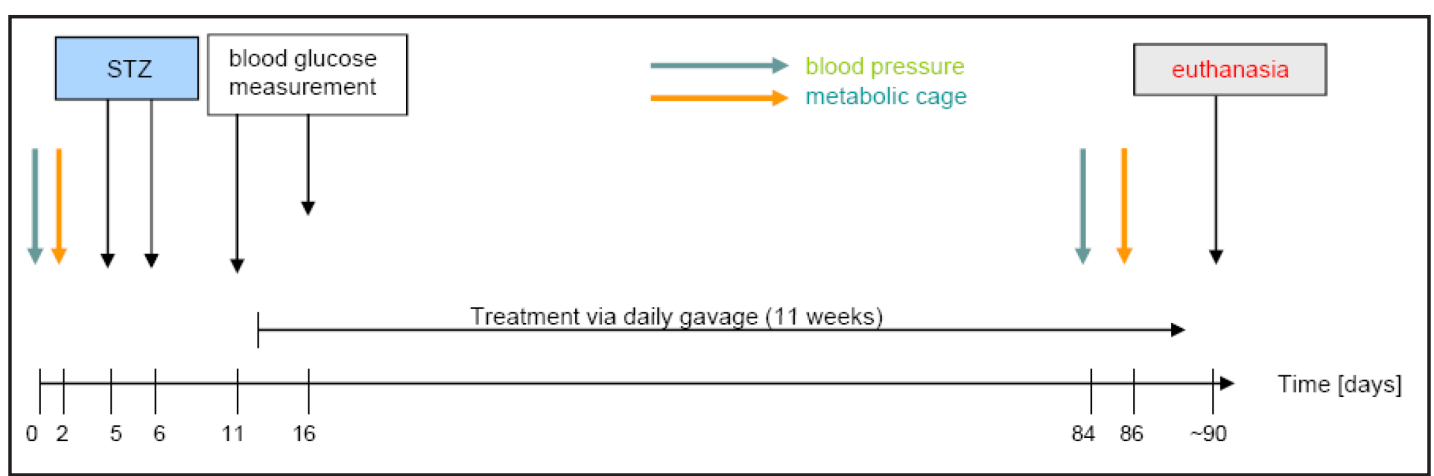

Fig. 1. Time course of the experiment.

libitum. Animal housing, care, and applications of experimental procedures complied with the Guide for the Care and Use of Laboratory Animals of the State Government of Brandenburg, Germany.

At the age of 7 weeks, 60 male eNOS (NOS3) knockout C57BL/6J mice (C57BL/6J-Nos3tm1Unc; obtained from The Jackson Laboratory, Bar Harbor, ME, USA) were randomly divided into four treatment groups 1.5 weeks after receiving intraperitoneal streptozotocin (STZ) $100 \mathrm{mg} / \mathrm{kg}$ on 2 consecutive days. Treatment groups were as follows: telmisartan (1 mg/kg; $\mathrm{n}=17$ ); linagliptin ( $3 \mathrm{mg} / \mathrm{kg} ; \mathrm{n}=14$ ); linagliptin + telmisartan (3 mg/kg + $1 \mathrm{mg} / \mathrm{kg} ; \mathrm{n}=12)$ and vehicle $(\mathrm{n}=17)$. Another 14 mice received vehicle after they had been administered citrate buffer without STZ in equal volume (non-diabetic controls). Before application of STZ, baseline measurement of BP and metabolic cages were performed to exclude preexisting differences between the study groups (week 0). All substances were given once daily by oral gavage with equal volumes per body weight. Before and several times during treatment, BG levels were measured to confirm hyperglycaemia ( $>250 \mathrm{mg} / \mathrm{dl}$ ) using a standard glucometer (Contour ${ }^{\mathrm{TM}}$, Bayer, Leverkusen, Germany). Animals that had only received citrate buffer were all non-diabetic $(<200 \mathrm{mg} / \mathrm{dl})$. Body weights were quantified daily immediately before gavage. After 11 weeks of treatment, experiments with metabolic cages were performed, urine and blood samples were obtained, and BP was measured. A detailed experiment schedule is outlined in Figure 1.

Biomarkers in plasma were measured using Rules Based Medicine (Cystatin C, Osteopontin) or Millipore platforms (GLP-1 active, tumour necrosis factor- $\alpha$ [TNF- $\alpha]$ ). Urinary albumin was measured using a multichannel autoanalyzer (Synchron CX7; Beckmann, Hamburg, Germany). Systolic blood pressure (SBP) was assessed via tail-cuff method.

\section{Histological studies}

Renal morphology (interstitial fibrosis, perivascular fibrosis, glomerulosclerosis and media-lumen ratio of blood vessels) was measured as described previously [24]. In brief, glomerular matrix expansion was evaluated on periodic acid-Schiff (PAS)-stained slides by rating the percentage of the PAS-positive areas within the glomerulus using a subjective, semi-quantitative score system (grade I-IV) by two investigators who were blinded to the study groups of the animals. The severity of interstitial fibrosis was evaluated after Sirius Red-staining using computer-aided devices. Thirty microscopic pictures per kidney section were transferred to a PowerMAC via Hitachi CCD camera. After manually setting a threshold using a randomly chosen subset of the pictures, we measured the relationship of Sirius Red-stained area (connective tissue) to total area of the picture using ImageJ, an image-processing software (shareware from the National Institutes of Health [NIH]). Accordingly, microscopic pictures of kidney sections after Elastica-van Gieson staining showed that arterial blood vessels were generated. We measured the area contents of the media and the lumen of intra-renal arteries using the ImageJ (shareware from the NIH); then media/lumen ratio was calculated to serve as marker for arterial wall thickening.

\section{Immunohistochemistry}

Deparaffinized kidney sections were quenched, blocked and incubated with primary antibody as follows: rabbit anti-mouse transforming growth factor $\beta 1$ (TGF- $\beta 1$ ) (1:50 dilution in $1.5 \%$ serum, Acris Antibodies $\mathrm{GmbH}$, Herford, Germany); rabbit anti-mouse plasminogen activator inhibitor-1 (PAI-1) (1:100, Santa Cruz Biotechnology, Inc., Santa Cruz, CA, USA); and rabbit anti-SDF-1 (1:50, Boehringer Ingelheim Pharma GmbH \& Co. KG). Overnight incubation at $4^{\circ} \mathrm{C}$ was followed by sequential application of biotinylated goat anti-rabbit immunoglobulin G (1:200 dilution for TGF $\beta-1$ and PAI-1; 1:50 dilution for SDF-1), avidin 


\section{Kidney \\ Blood Pressure Research}

Table 1: Baseline measurements (values are given as mean $\pm \mathrm{SEM}$ )

\begin{tabular}{lclcrr}
\hline & $\begin{array}{l}\text { Telmisartan } \\
1 \mathrm{mg} / \mathrm{kg}\end{array}$ & $\begin{array}{l}\text { Linagliptin } \\
3 \mathrm{mg} / \mathrm{kg}\end{array}$ & $\begin{array}{l}\text { Linagliptin } 3 \mathrm{mg} / \mathrm{kg}+ \\
\text { telmisartan } 1 \mathrm{mg} / \mathrm{kg}\end{array}$ & Diabetic, vehicle & Non-diabetic \\
\hline $\begin{array}{l}\text { Systolic blood pressure } \\
(\mathrm{mmHg})\end{array}$ & $116.4 \pm 2.4$ & $116.0 \pm 2.2$ & $122.0 \pm 2.4^{*}$ & $118.6 \pm 2.0$ & $122.3 \pm 2.3^{*}$ \\
\hline$* P<0.05$ vs diabetic vehicle. & & & & &
\end{tabular}

$* P<0.05$ vs diabetic vehicle.

Table 2: Final systolic blood pressure and urine and plasma parameters (values are given as means \pm SEM)

\begin{tabular}{lccccc}
\hline & $\begin{array}{c}\text { Telmisartan } \\
1 \mathrm{mg} / \mathrm{kg}\end{array}$ & $\begin{array}{c}\text { Linagliptin } \\
3 \mathrm{mg} / \mathrm{kg}\end{array}$ & $\begin{array}{c}\text { Linagliptin } 3 \mathrm{mg} / \mathrm{kg}+ \\
\text { telmisartan } 1 \mathrm{mg} / \mathrm{kg}\end{array}$ & Diabetic, vehicle & Non-diabetic \\
\hline $\begin{array}{l}\text { Systolic blood pressure } \\
\text { (mmHg) }\end{array}$ & $111.2 \pm 2.3$ & $120.2 \pm 1.6$ & $113.8 \pm 3.2$ & $117.1 \pm 2.2$ & $118.8 \pm 2.1$ \\
$\begin{array}{l}\text { Plasma-blood glucose } \\
(\mathrm{mg} / \mathrm{dl})\end{array}$ & $563.6 \pm 23.7^{*}$ & $525.4 \pm 36.3^{*}$ & $546.1 \pm 28.2^{*}$ & $517.7 \pm 28.6^{*}$ & $144.4 \pm 5.7^{*}$ \\
$\begin{array}{l}\text { Plasma- } \\
\begin{array}{l}\text { TNF- } \alpha \text { (ng/L) } \\
\text { Urinary albumin }\end{array}\end{array}$ & $10.9 \pm 2.4^{* *}$ & $11.8 \pm 2.4^{* *}$ & $13.5 \pm 2.6^{* *}$ & $20.8 \pm 1.5$ & $16.8 \pm 3.1$ \\
excretion $(\mu \mathrm{\mu g} / 24 \mathrm{~h})$ & $97.8 \pm 26.4$ & $120.8 \pm 37.7$ & $71.7 \pm 15.3^{* *}$ & $170.8 \pm 34.2$ & $31.4 \pm 10.6^{* *}$ \\
\hline${ }^{* P<0.05}$ vs non-diabetic; ${ }^{* *} P<0.05$ vs diabetic vehicle. & & & \\
\hline
\end{tabular}

and biotinylated horseradish peroxidase and DAB chromogen using an ABC-staining system (Santa Cruz Biotechnology, Inc., Santa Cruz, CA, USA). MDA-staining of deparaffinized kidney sections was performed using a goat anti-mouse antibody (1:200 dilution in 1.5\% serum, Immundiagnostik AG, Bensheim, Germany) and HRP-DAB System (R\&D Systems Europe Ltd., Abingdon, UK) following the manufacturer's procedure. Negative controls for immunostaining included omission of the corresponding primary antibody. All sections were lightly counterstained with haematoxylin.

Immunostaining was graded on blinded sections by two independent investigators using a semiquantitative score. Glomerular expression of TGF $\beta-1$, PAI-1 and SDF-1 was carried out in 40-50 glomerular cross-sections taking into account absent, podocytic and mesangial staining. Analysis of MDA stained kidney slices was done by analogy of interstitial fibrosis evaluation using 15 pictures of each animal.

Statistical analyses

All values are given as means \pm standard error of the mean (SEM). Statistical analyses were performed with SPSS 18.0 for Windows (SPSS Inc., Chicago, IL, USA). For comparisons between two groups of interest, the unpaired Student's $t$-test was used if variables were parametric and normally distributed, which was tested by Kolmogorow-Smirnov test. Otherwise, Wilcoxon-Mann-Whitney U test was used. Mortality calculations were performed using Kaplan-Meier analysis and Mantel-Cox log-rank test. Differences were considered significant if $P<0.05$ and highly significant if $P<0.01$.

\section{Results}

Baseline measurements, blood glucose and mortality

Baseline measurements of SBP before application of STZ revealed no significant differences between the study groups (Table 1). Furthermore, baseline metabolic cage experiments revealed no differences with regard to BG (Table 1), urinary albumin and creatinine excretion and diuresis volume (data not shown). After baseline measurements, BG was significantly higher in all diabetic groups compared with the non-diabetic control groups throughout the entire experiment (Table 1). BG levels were similar across the diabetic groups. Analyses revealed no significant differences in mortality (log rank, $P=0.25$; data not shown).

\section{Blood pressure and cystatin $C$}

At the end of the experiment, SBP in animals that were treated with telmisartan alone was modestly reduced by $5.9 \mathrm{mmHg}$ versus diabetic control $(P=0.071$; Table 2$)$, whereas the 


\section{Kidney Blood Pressure Research}

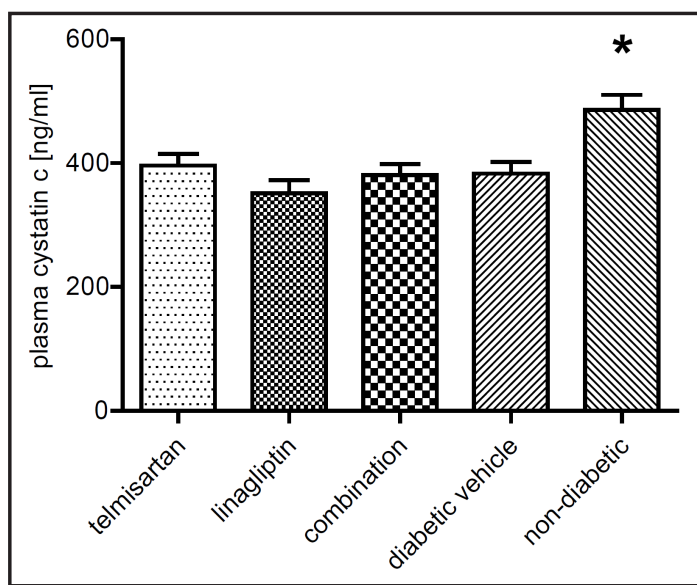

Fig. 2. Plasma cystatin $C$ values (final measurement) are given as means \pm SEM. ${ }^{*} P<0.05$ vs diabetic vehicles.

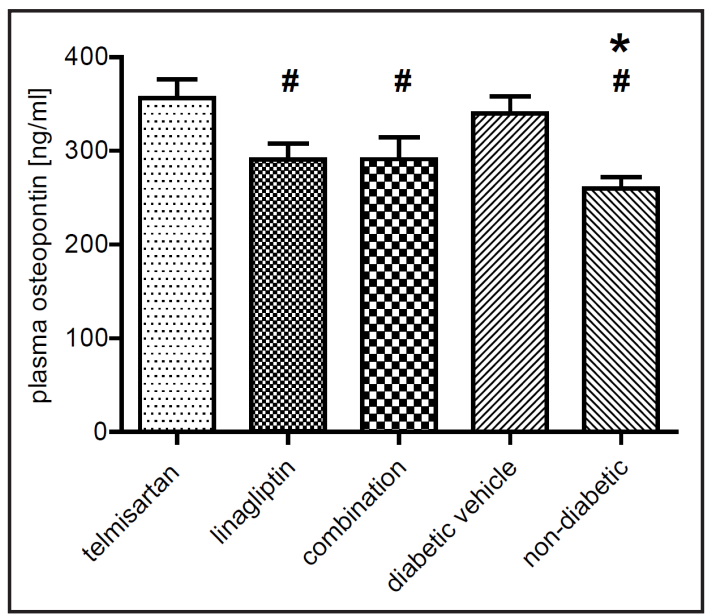

Fig. 4. Plasma osteopontin levels (final measurements; values are given as means \pm SEM). ${ }^{*} P<0.05$ vs telmisartan; ${ }^{* *} P<0.05$ vs diabetic vehicles.

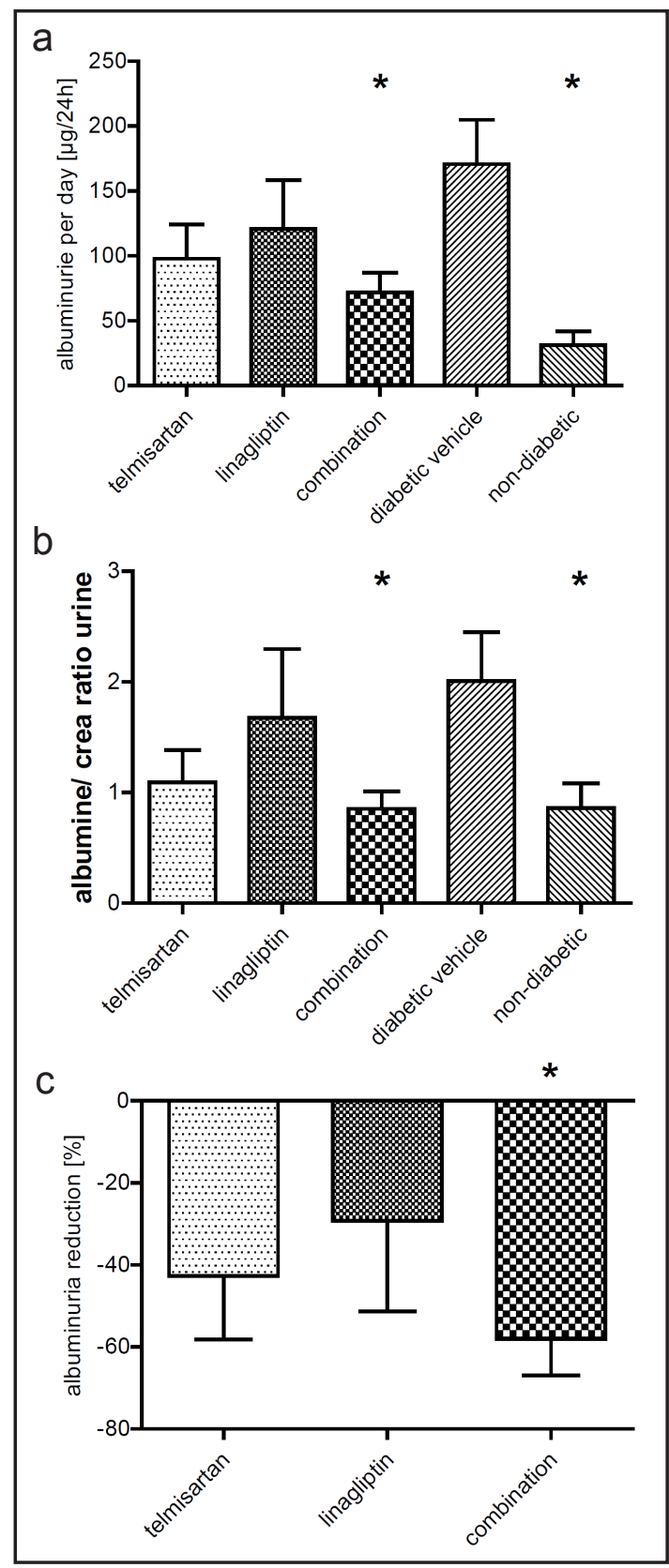

Fig. 3. Changes in albuminuria values (final measurement) are given as means \pm SEM. (a) urinary albumin excretion per $24 \mathrm{~h}$. (b) Urinary albumin/ creatinine ratio. (c) Reduction in urinary albumin excretion (\%) per $24 \mathrm{~h}$ in comparison to diabetic vehicles (their mean value equates to 0 ). Nondiabetic animals were not included to achieve better clarity. ${ }^{*} P<0.05$ vs diabetic vehicles.

combination therapy reduced SBP by $3.3 \mathrm{mmHg}$ versus diabetic control $(P=0.392)$. None of the differences between treatments reached statistical significance. All diabetic animals had similar cystatin C levels (Figure 2), which were significantly lower compared with the nondiabetic controls $(P<0.05$ for each), and demonstrated that kidney dysfunction was similar in all groups. 


\section{Kidney \\ Blood Pressure Research}

Table 3: Kidney weight and histology (values are given as means \pm SEM)

\begin{tabular}{lccccc}
\hline & $\begin{array}{c}\text { Telmisartan } \\
1 \mathrm{mg} / \mathrm{kg}\end{array}$ & $\begin{array}{c}\text { Linagliptin } \\
3 \mathrm{mg} / \mathrm{kg}\end{array}$ & $\begin{array}{c}\text { Linagliptin } 3 \mathrm{mg} / \mathrm{kg}+ \\
\text { telmisartan } 1 \mathrm{mg} / \mathrm{kg}\end{array}$ & Diabetic, vehicle & Non-diabetic \\
\hline $\begin{array}{l}\text { Relative weight right } \\
\text { kidney (mg/g) }\end{array}$ & $8.0 \pm 0.5$ & $7.5 \pm 0.4$ & $7.6 \pm 0.3$ & $7.3 \pm 0.4$ & $5.0 \pm 0.2^{*}$ \\
$\begin{array}{l}\text { Relative weight left } \\
\text { kidney (mg/g) }\end{array}$ & $8.2 \pm 0.4$ & $7.5 \pm 0.4$ & $7.7 \pm 0.5$ & $7.6 \pm 0.6$ & $5.1 \pm 0.2^{*}$ \\
$\begin{array}{l}\text { Kidney interstitial } \\
\text { fibrosis (\%) }\end{array}$ & $0.7 \pm 0.1$ & $0.6 \pm 0.1$ & $0.7 \pm 0.1$ & $0.8 \pm 0.1$ & $0.5 \pm 0.2$ \\
$\begin{array}{l}\text { Glomerulosclerosis } \\
\text { (score) }\end{array}$ & $2.2 \pm 0.1$ & $2.1 \pm 0.0^{*}$ & $2.1 \pm 0.1^{*}$ & $2.4 \pm 0.1$ & $2.4 \pm 0.1$ \\
\hline$* P<0.05$ vs diabetic vehicle. & & & &
\end{tabular}

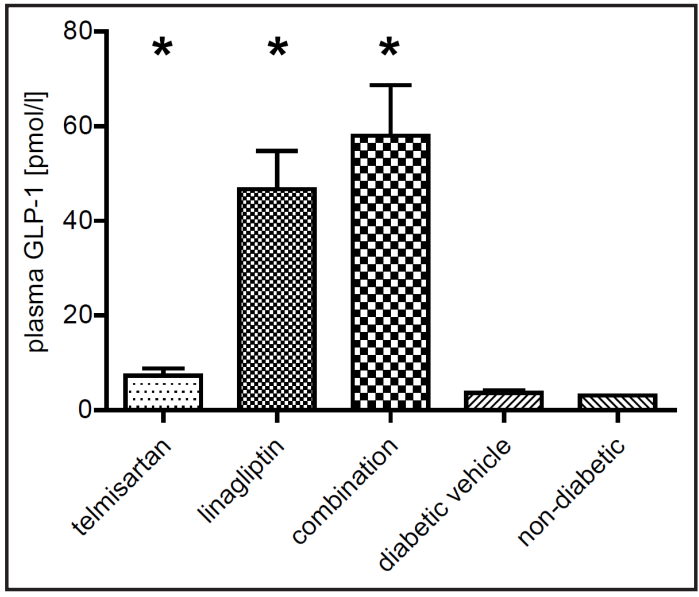

Fig. 5. Plasma active glucagon-like peptide-1 levels (final measurements; values are given as means \pm SEM). ${ }^{*} P<0.05$ vs diabetic vehicles.



Fig. 6. Percentage of MDA positive area in kidney tissue samples (values are given as means \pm SEM). **, $* * * \mathrm{P}<0.01 ; \mathrm{P}<0.001$ vs diabetic vehicles.

\section{Urinary biomarkers}

Combination treatment with linagliptin and telmisartan significantly reduced 24-h urinary albumin excretion and the albumin/creatinine ratio compared with diabetic controls $(P=0.017$; Figures 3A and 3B; Table 2). However, the effects of telmisartan or linagliptin alone on albumin endpoints were not statistically significant. The combination treatment significantly reduced albuminuria by $58.0 \%$ (Figure 3C). Furthermore, the combined treatment led to an excretion level close to that of the non-diabetic controls.

\section{Plasma biomarkers}

Linagliptin alone and in combination led to significantly lower plasma osteopontin levels $(290.8 \pm 17.0 \mu \mathrm{g} / \mathrm{L}[\mathrm{n}=13]$ and $291.0 \pm 23.5 \mu \mathrm{g} / \mathrm{L}[\mathrm{n}=12]$, respectively) compared with telmisartan alone $(356.4 \pm 20.1 \mu \mathrm{g} / \mathrm{L}[\mathrm{n}=14] ; P=0.021$ and $P=0.044$, respectively). Telmisartan values for osteopontin were similar to diabetic controls $(340.1 \pm 17.9 \mu \mathrm{g} / \mathrm{L} ; \mathrm{n}$ = 14; Figure 4). Differences between the diabetic controls and the linagliptin groups were not statistically significant $(P=0.059$ vs linagliptin alone and $P=0.105$ vs linagliptin + telmisartan). Plasma TNF- $\alpha$ concentrations were significantly lower in all treatment groups compared with the untreated diabetic control group (Table 2). As a matter of proof, plasma levels of active GLP-1 were highly increased in both linagliptin groups compared with the other groups (Figure 5 and Table 2). 


\section{Kidney Blood Pressure Research}

Kidney Blood Press Res 2012;36:119-130

\begin{tabular}{l|l}
\hline DOI: $10.1159 / 000341487$ & (c) 2012 S. Karger AG, Basel \\
www.karger.com/kbr
\end{tabular}

Alter/Ott/von Websky et al.: DPP4 Inhibition in Experimental Diabetic Nephropathy

Organs and histology

Relative organ weights (i.e. organ weights per body weight) did not differ between the treatment groups (Table 3). However, the relative weights of liver and kidneys were significantly higher in diabetic animals compared with non-diabetic animals. Interstitial fibrosis in the kidneys was highest in diabetic control animals and lowest in non-diabetic control animals, whereas the drug-treated animals ranged in between. Differences, however, were not statistically significant (Table 3). Perivascular fibrosis and media lumen ratio in the kidneys revealed no differences between the study groups (data not shown). Linagliptin, alone and in combination with telmisartan, led to a significantly reduced glomerulosclerosis score compared with diabetic controls $(P=0.002$ for linagliptin alone and $P=0.027$ for combination, respectively), whereas the reduction achieved by telmisartan alone was not significantly different $(P=0.056$; Table 3$)$. Immunohistochemical staining of the kidneys revealed no differences between the study groups with regard to glomerular and interstitial TGF- $\beta 1$, PAI-1 and SDF-1 expression (data not shown). Staining for renal malonaldehyde immune-reactivity, a marker of oxidative stress, revealed a significant increase in vehicle treated diabetic animals as compared with non-diabetic controls. DPP-4 inhibition with and without telmisartan prevented this increase and therefore showed significantly lower expression rates as compared with diabetic vehicle (Fig. 6), whereas telmisartan alone had no significant beneficial effects on MDA expression.

\section{Discussion}

The overall goal of this study was to investigate the effect of the DPP-4 inhibitor linagliptin, alone and in combination with guideline-based treatment with an ARB (telmisartan), on the progression of diabetic nephropathy in a mouse model closely resembling human diabetic nephropathy in terms of clinical course and pathology. In contrast to telmisartan alone, treatment with linagliptin plus telmisartan significantly reduced urinary albumin excretion in diabetic mice in a blood pressure-independent manner. Additionally, linagliptin treatment (either alone or with telmisartan) reduced plasma levels of the vascular calcification marker osteopontin compared with telmisartan alone. By contrast, osteopontin values in the telmisartan group were similar to diabetic vehicle. Moreover, the tissue immune-reactivity of malondialdehyde, a biomarker of oxidative stress, was normalized by DPP-4 inhibition with linagliptin, whereas angiotensin II receptor blockade alone failed to reduce oxidative stress in diabetic eNOS knockout mice. Glomerulosclerosis was significantly lower in the linagliptin groups in contrast to telmisartan alone.

The chosen animal model is robust and mimics many aspects of human diabetic nephropathy such as loss of glomerular filtration rate (GFR), glomerular and tubulointerstitial pathology, and albuminuria [7, 21-23]. Results for plasma cystatin C showed that the experiment had been finished in an early, still hyperfiltrating stage [25]. From a clinical point of view, the knockout of the eNOS gene resembles pathology in diabetic patients who frequently suffer from endothelial dysfunction, showing functional loss of eNOS activity.

Supporting this clinical observation, genetic studies have shown that polymorphisms of the eNOS (NOS3) gene with a consecutive lower production of the important vascular modulator NO [26-28] were associated with the development of nephropathy in patients with T1DM or T2DM $[29,30]$. Moreover, this pathogenetic mechanism is intensively discussed as causal for patients with diabetes who are still developing overt nephropathy despite optimal therapy including ARBs [4, 9, 31,32]. Moreover, there is evidence that RAS blockade ameliorated renal injury in diabetic wild type mice but not in diabetic eNOS knock out mice, indicating that impaired NO bioavailability was responsible for resistance to RAS blockade [7]. In the present study, treatment with telmisartan alone slightly lowered urinary albumin excretion but failed the statistical significance test $(P=0.101)$, whereas linagliptin plus telmisartan led to significantly lower urinary albumin excretion and albumin/creatinine ratio (Figure 3). 


\section{Kidney Blood Pressure Research}

Urinary albumin excretion is a very early stage predictor for the development and progression of diabetic nephropathy, signaling renal damage when other markers such as plasma creatinine and cystatin C levels are unremarkable [8, 33, 34]. Albuminuria is not only associated with renal and cardiovascular morbidity and mortality in patients with diabetes $[33,35,36]$ but also can predict cardiovascular and non-cardiovascular events in healthy patients $[37,38]$. Hence, the reduction of albuminuria in our experiment is of clinical importance.

It is noteworthy that our results appeared independently of changes in BG and SBP. BG levels were highly increased in diabetic animals, and treatment did not have significant influence on glucose. Given that linagliptin increases endogenous insulin release via augmentation of plasma GLP-1, this observation in STZ-treated mice was not surprising [39]. In any case, treatment with linagliptin led to highly elevated plasma GLP-1 levels compared with all other study groups (Figure 5), confirming that linagliptin was administered in an adequate dosage [40]. The study was designed with the intention that telmisartan would be used in a non-BP-lowering dose to avoid BP-lowering effects that might on their own influence the primary endpoint albuminuria [7]. Telmisartan alone slightly reduced SBP without significance $(P=0.071)$, and combination therapy completely lacked significance $(P=$ 0.392 ) compared with diabetic control animals. Indeed, RAS blockers are usually intended to lower BP in patients and are therefore administered in dosages as high as possible. However, in the current model the increase of RAS blocker dosage does not necessarily reduce SBP, as was recently shown by Kosugi and colleagues [7]. Telmisartan in similar dosages of ours (2 $\mathrm{mg} / \mathrm{kg}$ per day and body weight) only slightly reduced SBP, whereas enalapril in dosages of up to $50 \mathrm{mg} / \mathrm{kg}$ showed at most only transient SBP lowering effects. Furthermore, neither albuminuria nor renal injuries were effectively reduced by telmisartan $(2 \mathrm{mg} / \mathrm{kg})$ and ramipril (independently of the chosen dosage), respectively. As these results stand in line with our findings, it appears unlikely that we would have seen any further beneficial telmisartan effects if we had increased the dosage, underlining the therapeutical insufficiency of RAS blockade in this model, independently of SBP control. Moreover, as depicted in table 1 , baseline SBP measurements revealed a significant increase in the combination group despite animals had not received any treatment at that time of experiment. We believe that this difference is caused by chance. However, if not and that differences was of impact, we would expect less observed benefits in the combination group as compared to the other groups since SBP is a risk factor of diabetic nephropathy and vasculopathy. Hence, this observation potentially underlines our conclusions.

Histologic analyses support our findings concerning albuminuria. Glomerulosclerosis score as the morphologic surrogate of diabetic kidney damage was significantly reduced in animals that were treated with linagliptin, alone and in combination, compared with diabetic controls. As eNOS knock out and hypertension themselves [41] state a major renal risk factor which is at most only aggravated by hyperglycemia, glomerulosclerosis does not statistically differ between diabetic and non-diabetic control animals. In contrast to heart tissue [10], where the beneficial effects of DPP-4 inhibition could most likely be attributed to enhanced recruitment of CXCR-4+ circulating progenitor cells as a result of reduced cleavage of SDF-1 $\alpha$, our immunohistologic findings did not support this pathway. However, evidence [42] suggests a link between diabetes, DPP-4 inhibitors and the vascular calcification marker osteopontin $[43,44]$ which was significantly reduced in animals that had been treated with linagliptin compared with telmisartan alone. We were able to show that long-term treatment with linagliptin reduced plasma levels of osteopontin, compared with treatment with telmisartan alone, where levels were similar to the diabetic control group. Osteopontin is known to be associated with vascular calcification and cardiovascular morbidity in humans [44] and has already been called "the killer of patients with CKD" [43]. These findings support those from short-term treatment in a chronic renal failure model in rats [11].

However, linagliptin-related enhancement of plasma GLP-1 levels probably also accounts for direct renoprotective actions. GLP-1 receptors (GLP-1Rs) are expressed in the kidney, heart and vasculature, and recent studies have shown that GLP-1R agonists have 


\section{Kidney \\ Blood Pressure Research}

cardiovascular benefits that are independent of improved glucose homeostasis such as modulation of heart rate, BP, vascular tone and myocardial contractility [45]. Furthermore, Kodera and colleagues [12] have recently demonstrated that the GLP-1R agonist exendin-4 exerts renoprotective effects through its anti-inflammatory action via GLP-1R without lowering BG. In the present study we show that similar effects were achieved by inhibition of DPP-4, which resulted in highly increased plasma GLP-1 levels (Figure 5). Moreover, we have shown that DPP-4 inhibition significantly reduced renal malonaldehyde immune-reactivity in diabetic eNOS knock out mice (Figure 6). Reactive oxygen species degrade polyunsaturated lipids, forming malondialdehyd, a reactive aldehyde, that is a reactive electrophile species that causes toxic stress in cells and forms covalent protein adducts referred to as advanced lipoxidation end-products (ALE) [46]. Malondialdehyde is thus a biomarker of the tissue concentration of reactive oxygen species and its tissue damage and is widely used for the assessment of oxidative stress [47, 48].

Oxidative stress is thought to play a major role in the pathogenesis of diabetic nephropathy [48-50]. In this context, it is of note that the GLP-1 analog liraglutide likewise reduced oxidative stress in a rat model of diabetic nephropathy via a GLP-1 receptor- PKAmediated inhibition of renal NAD(P)H oxidase (Nox4) [51]. GLP-1 plasma concentrations were substantially increased in our in vivo study (Figure 5). Recent studies likewise demonstrated that linagliptin inhibits NAD(P)H oxidase in vitro and in vivo [52].

Finally, treatment with either linagliptin, telmisartan, or both led to significantly lower plasma TNF- $\alpha$ levels compared with diabetic control animals, supporting the hypothesis of lower inflammatory activity in the treatment groups. In contrast to exendin- 4 and GLP-1, linagliptin can be orally administered once daily and is approved for use in patients with declining renal function without the need for dose adjustment, which is a benefit for patients with diabetic nephropathy.

\section{Conclusion}

In conclusion, this study showed for the first time that additional treatment on top of ARB with the DPP-4 inhibitor linagliptin may offer a new therapeutic approach for patients with diabetic nephropathy. It would be of interest to analyze potential effects of linagliptin in non-diabetic models of chronic renal failure as well, since the observed effects were independent of the glucose lowering effects of linagliptin. Moreover, our findings should stimulate investigators to perform clinical studies using either suitable biomarker strategies for phase 2 studies [53-56] or hard clinical endpoints typically used in phase 3 registration trails for chronic renal failure such as doubling of serum creatinine, need for renal replacement therapy and total mortality [57] investigation the effects of linagliptin in patients with diabetic nephropathy.

\section{Acknowledgements}

Dr. Thomas Klein is a research employee of Boehringer Ingelheim Pharma GmbH \& Co. KG. This study was supported by a research grant from Boehringer Ingelheim Pharma GmbH \& Co. KG, Germany, to Dr. Berthold Hocher.

\section{References}

1 Tomson C, Udayaraj U, Gilg J, Ansell D: Comorbidities in UK patients at the start of renal replacement therapy. Nephrol Dial Transplant 2007;22:vii58-68. 


\section{Kidney \\ Blood Pressure Research}

Kidney Blood Press Res 2012;36:119-130

\begin{tabular}{l|l}
\hline DOI: $10.1159 / 000341487$ & (c) 2012 S. Karger AG, Basel \\
\hline
\end{tabular}

Published online: October 15, 2012

www.karger.com/kbr

Alter/Ott/von Websky et al.: DPP4 Inhibition in Experimental Diabetic Nephropathy

-2 Mann JFE, Schmieder RE, McQueen M, Dyal L, Schumacher H, Pogue J, Wang X, Maggioni A, Budaj A, Chaithiraphan S, Dickstein K, Keltai M, Metsärinne K, Oto A, Parkhomenko A, Piegas LS, Svendsen TL, Teo KK, Yusuf S: Renal outcomes with telmisartan, ramipril, or both, in people at high vascular risk (the ONTARGET study): a multicentre, randomised, double-blind, controlled trial. Lancet 2008;372:547-553.

- 3 Yusuf S, Teo KK, Pogue J, Dyal L, Copland I, Schumacher H, Dagenais G, Sleight P, Anderson C: Telmisartan, ramipril, or both in patients at high risk for vascular events. N Engl J Med 2008;358:1547-1559.

-4 Higashi Y, Sasaki S, Nakagawa K, Ueda T, Yoshimizu A, Kurisu S, Matsuura H, Kajiyama G, Oshima T: A comparison of angiotensin-converting enzyme inhibitors, calcium antagonists, beta-blockers and diuretic agents on reactive hyperemia in patients with essential hypertension: a multicenter study. J Am Coll Cardiol 2000;35:284-291.

-5 Jandeleit-Dahm KAM, Tikellis C, Reid CM, Johnston CI, Cooper ME: Why blockade of the renin-angiotensin system reduces the incidence of new-onset diabetes. J Hypertens 2005;23:463-473.

6 Burnier M: Angiotensin II type 1 receptor blockers. Circulation 2001;103:904-912.

7 Kosugi T, Heinig M, Nakayama T, Matsuo S, Nakagawa T: eNOS knockout mice with advanced diabetic nephropathy have less benefit from renin-angiotensin blockade than from aldosterone receptor antagonists. Am J Pathol 2010;176:619-629.

8 Makino H, Haneda M, Babazono T, Moriya T, Ito S, Iwamoto Y, Kawamori R, Takeuchi M, Katayama S: Prevention of transition from incipient to overt nephropathy with telmisartan in patients with type 2 diabetes. Diabetes care 2007;30:1577-1578.

9 Schmieder RE, Delles C, Mimran A, Fauvel JP, Ruilope LM: Impact of telmisartan versus ramipril on renal endothelial function in patients with hypertension and type 2 diabetes. Diabetes care 2007;30:1351-1356.

10 Hocher B, Sharkovska Y, Mark M, Klein T, Pfab T: The novel DPP-4 inhibitors linagliptin and BI 14361 reduce infarct size after myocardial ischemia/reperfusion in rats. Int J Cardiol DOI: $\underline{10.1016 / \mathrm{j}}$. ijcard.2011.12.007.

11 Chaykovska L, von Websky K, Rahnenführer J, Alter ML, Heiden S, Fuchs H, Runge F, Klein T, Hocher B: Effects of DPP-4 inhibitors on the heart in a rat model of uremic cardiomyopathy. PlosO one 2011;6:e27861.

-12 Hocher B, Reichetzeder C, Alter M. Renal and Cardiac Effects of DPP4 Inhibitors. Kidney Blood Press Res 2012; 36:65-84.

13 Vickers SP, Cheetham SC, Birmingham GD, Rowley HL, Headland KR, Dickinson K, Grempler R, Hocher B, Mark M, Klein T. Effects of the DPP-4 Inhibitor, Linagliptin, in Diet-Induced Obese Rats: A Comparison in Naive and Exenatide-Treated Animals. Clin. Lab 2012;58:787-799.

14 Nauck MA: Glucagon-like peptide 1 (GLP-1) in the treatment of diabetes. Horm Metab Res DOI:10.1055/s-2004-826175.

15 Ahrén B, Simonsson E, Larsson H, Landin-Olsson M, Torgeirsson H, Jansson P-A, Sandqvist M, Båvenholm P, Efendic S, Eriksson JW, Dickinson S, Holmes D: Inhibition of dipeptidyl peptidase IV improves metabolic control over a 4-week study period in type 2 diabetes. Diabetes care 2002;25:869-875.

-16 Bergman AJ, Stevens C, Zhou YY, Yi B, Laethem M, Smet M, Snyder K, Hilliard D, Tanaka W, Zeng W, Tanen M, Wang AQ Chen L, Winchell G, Davies M, Ramael S, Wagner JA, Herman GA: Pharmacokinetic and pharmacodynamic properties of multiple oral doses of sitagliptin, a dipeptidyl peptidase-IV inhibitor: a double-blind, randomized, placebo-controlled study in healthy male volunteers. Clin Ther 2006;28:55-72.

-17 Deacon C, Holst JJ: Linagliptin, a xanthine-based dipeptidyl peptidase-4 inhibitor with an unusual profile for the treatment of type 2 diabetes. Expert Opin Investig Drugs 2010;19:133-140.

18 Graefe-Mody EU, Padula S, Ring A, Withopf B, Dugi KA: Evaluation of the potential for steady-state pharmacokinetic and pharmacodynamic interactions between the DPP-4 inhibitor linagliptin and metformin in healthy subjects. Curr Med Res Opin 2009;25:1963-1972.

-19 Hüttner S, Graefe-Mody EU, Withopf B, Ring A, Dugi KA: Safety, tolerability, pharmacokinetics, and pharmacodynamics of single oral doses of BI 1356, an inhibitor of dipeptidyl peptidase 4, in healthy male volunteers. J Clin Pharmacol 2008;48:1171-1178.

-20 Heise T, Graefe-Mody EU, Hüttner S, Ring A, Trommeshauser D, Dugi K: Pharmacokinetics, pharmacodynamics and tolerability of multiple oral doses of linagliptin, a dipeptidyl peptidase- 4 inhibitor in male type 2 diabetes patients. Diabetes Obes Metab 2009;11:786-794.

-21 Brosius F, Alpers CE, Bottinger EP, Breyer MD, Coffman TM, Gurley SB, Harris RC, Kakoki M, Kretzler M, Leiter EH, Levi M, McIndoe RA, Sharma K, Smithies O, Susztak K, Takahashi N, Takahashi T: Mouse models of diabetic nephropathy. J Am Soc Nephrol 2009;20:2503-2512.

22 Kanetsuna Y, Takahashi K, Nagata M, Gannon MA, Breyer MD, Harris RC, Takahashi T: Deficiency of endothelial nitric-oxide synthase confers susceptibility to diabetic nephropathy in nephropathy-resistant inbred mice. Am J Pathol 2007;170:1473-1484. 


\section{Kidney \\ Blood Pressure Research}

Kidney Blood Press Res 2012;36:119-130

\begin{tabular}{l|l}
\hline DOI: $10.1159 / 000341487$ & (c 2012 S. Karger AG, Basel
\end{tabular}

Published online: October 15, 2012

www.karger.com $/ \mathrm{kbr}$

Alter/Ott/von Websky et al.: DPP4 Inhibition in Experimental Diabetic Nephropathy

-23 Nakagawa T, Sato W, Glushakova O, Heinig M, Clarke T, Campbell-Thompson M, Yuzawa Y, Atkinson MA, Johnson RJ, Croker B: Diabetic endothelial nitric oxide synthase knockout mice develop advanced diabetic nephropathy. J Am Soc Nephrol 2007;18:539-550.

24 Sharkovska Y, Kalk P, von Websky K, Relle K, Pfab T, Alter M, Fischer Y, Hocher B.. Renoprotective Effects of Combined Endothelin-Converting Enzyme / Neutral Endopeptidase Inhibitor SLV338 in Acute and Chronic Experimental Renal Damage. Clin Lab 2011;57:507-515.

-25 Zatz R, Dunn B, Meyer TW, Anderson S, Rennke H, Brenner B: Prevention of diabetic glomerulopathy by pharmacological amelioration of glomerular capillary hypertension. J Clin Invest 1986;77:1925-1930.

-26 Nakayama M, Yasue H, Yoshimura M, Shimasaki Y, Kugiyama K, Ogawa H, Motoyama T, Saito Y, Ogawa Y, Miyamoto Y, Nakao K: T-786--C mutation in the 5'-flanking region of the endothelial nitric oxide synthase gene is associated with coronary spasm. Circulation 1999;99:2864-2870.

27 Tsukada T, Yokoyama K, Arai T, Takemoto F, Hara S, Yamada A, Kawaguchi Y, Hosoya T, Igari J: Evidence of association of the ecNOS gene polymorphism with plasma NO metabolite levels in humans. Biochem Biophys Res Commun 1998;245:190-193.

-28 Veldman BA, Spiering W, Doevendans PA, Vervoort G, Kroon AA, Leeuw PW, Smits P: The Glu298Asp polymorphism of the NOS 3 gene as a determinant of the baseline production of nitric oxide. J Hypertens 2002;20:2023-2027.

29 Zanchi A, Moczulski DK, Hanna LS, Wantman M, Warram JH, Krolewski AS: Risk of advanced diabetic nephropathy in type 1 diabetes is associated with endothelial nitric oxide synthase gene polymorphism. Kidney Int 2000;57:405-413.

-30 Ezzidi I, Mtiraoui N, Mohamed MBH, Mahjoub T, Kacem M, Almawi W: Association of endothelial nitric oxide synthase Glu298Asp, 4b/a, and -786TC gene variants with diabetic nephropathy. J Diabetes Complicat 2008;22:331-338.

-31 Brosius FC: New insights into the mechanisms of fibrosis and sclerosis in diabetic nephropathy. Rev Endocr Metab Disord 2008;9:245-254.

-32 Futrakul N, Butthep P, Vongthavarawat V, Futrakul P, Sirisalipoch S, Chaivatanarat T, Suwanwalaikorn S: Early detection of endothelial injury and dysfunction in conjunction with correction of hemodynamic maladjustment can effectively restore renal function in type 2 diabetic nephropathy. Clin Hemorheol Microcirc 2006;34:373-381.

-33 Ritz E, Schmieder RE, Pollock CA: Renal protection in diabetes: lessons from ONTARGET. Cardiovasc Diabetol 2010;9:60.

34 Ladeia AM, Ladeia-Frota C, Pinho L, Stefanelli E, Adan L: Endothelial dysfunction is correlated with microalbuminuria in children with short-duration type 1 diabetes. Diabetes care 2005;28:2048-2050.

-35 de Zeeuw D, Remuzzi G, Parving H-H, Keane WF, Zhang Z, Shahinfar S, Snapinn S, Cooper ME, Mitch WE, Brenner BM: Proteinuria, a target for renoprotection in patients with type 2 diabetic nephropathy: lessons from RENAAL. Kidney Int 2004;65:2309-2320.

-36 Iseki K, Ikemiya Y, Iseki C, Takishita S: Proteinuria and the risk of developing end-stage renal disease. Kidney Int 2003;63:1468-1474.

37 Arnlöv J, Evans JC, Meigs JB, Wang TJ, Fox CS, Levy D, Benjamin EJ, D'Agostino RB, Vasan RS: Low-grade albuminuria and incidence of cardiovascular disease events in nonhypertensive and nondiabetic individuals: the Framingham Heart Study. Circulation 2005;112:969-975.

-38 Hillege HL, Fidler V, Diercks GFH, van Gilst WH, Zeeuw D, van Veldhuisen DJ, Gans ROB, Janssen WMT, Grobbee DE, Jong PE: Urinary albumin excretion predicts cardiovascular and noncardiovascular mortality in general population. Circulation 2002;106:1777-1782.

-39 Nagakura T, Yasuda N, Yamazaki K, Ikuta H, Tanaka I: Enteroinsular axis of db/db mice and efficacy of dipeptidyl peptidase IV inhibition. Metab Clin Exp 2003; 52:81-86.

40 Thomas L, Tadayyon M, Mark M: Chronic treatment with the dipeptidyl peptidase-4 inhibitor BI 1356 [(R)-8-(3-amino-piperidin-1-yl)-7-but-2-ynyl-3-methyl-1-(4-methyl-quinazolin-2-ylmethyl)-3,7-dihydropurine-2,6-dione] increases basal glucagon-like peptide-1 and improves glycemic control in diabetic rodent models. J Pharmacol Exp Ther 2009;328:556-563.

-41 Klag MJ, Whelton PK, Randall BL, Neaton JD, Brancati FL, Ford CE, Shulman NB, Stamler J: Blood pressure and end-stage renal disease in men. N Engl J Med 1996;334:13-18.

-42 Senkel S, Lucas B, Klein-Hitpass L, Ryffel GU: Identification of target genes of the transcription factor HNF1 beta and HNF1alpha in a human embryonic kidney cell line. Biochim Biophys Acta 2005;1731:179190.

43 Mizobuchi M, Towler D, Slatopolsky E: Vascular calcification: the killer of patients with chronic kidney disease. J Am Soc Nephrol 2009;20:1453-1464. 


\section{Kidney \\ Blood Pressure Research}

Kidney Blood Press Res 2012;36:119-130

DOI: 10.1159/000341487

Published online: October 15, 2012

C 2012 S. Karger AG, Basel

www.karger.com/kbr

-44 Yan X, Sano M, Lu L, Wang W, Zhang Q, Zhang R, Wang L, Chen Q, Fukuda K, Shen W: Plasma concentrations of osteopontin, but not thrombin-cleaved osteopontin, are associated with the presence and severity of nephropathy and coronary artery disease in patients with type 2 diabetes mellitus. Cardiovasc Diabetol 2010;9:70.

45 Grieve DJ, Cassidy RS, Green BD: Emerging cardiovascular actions of the incretin hormone glucagon-like peptide-1: potential therapeutic benefits beyond glycaemic control? Br J Pharmacol 2009;157:1340-1351.

46 Del Rio D, Stewart AJ, Pellegrini N: A review of recent studies on malondialdehyde as toxic molecule and biological marker of oxidative stress. Nutr Metab Cardiovasc Dis 2005;15:316-328.

47 Siems W, Quast S, Carluccio F, Wiswedel I, Hirsch D, Augustin W, Hampi H, Riehle M, Sommerburg O: Oxidative stress in chronic renal failure as a cardiovascular risk factor. Clin Nephrol 2002;58:S12-S19.

48 Suzuki D, Miyata T, Saotome N, Horie K, Inagi R, Yasuda Y, Uchida K, Izuhara Y, Yagame M, Sakai H, Kurokawa K: Immunohistochemical evidence for an increased oxidative stress and carbonyl modification of proteins in diabetic glomerular lesions. J Am Soc Nephrol 2009;10:822-832.

49 Onozato ML, Tojo A, Goto A, Fujita T, Wilcox CS: Oxidative stress and nitric oxide synthase in rat diabetic nephropathy: effects of ACEI and ARB. Kidney Int 2002;61:186-194.

50 Horie K, Miyata T, Maeda K, Miyata S, Sugiyama S, Sakai H, van Ypersole Strihou C, Monnier VM, Witztum JL, Kurokawa K: Immunohistochemical colocalization of glycoxidation products and lipid peroxidation products in diabetic renal glomerular lesions. Implication for glycoxidative stress in the pathogenesis of diabetic nephropathy. J Clin Invest 1997;100:2995-3004.

-51 Hendarto H, Inoguchi T, Maeda Y, Ikeda N, Zheng J, Takei R, Yokomizo H, Hirata E, Sonoda N, Takayanagi R: GLP-1 analog liraglutide protects against oxidative stress and albuminuria in streptozotocininduced diabetic rats via protein kinase A-mediated inhibition of renal NAD(P)H oxidases. Metabolism 2012;61:1422-1434.

52 Schuff A, Steven S, Schell R, Schuhmacher S, Oelze M, Knorr M, Hausding M, Daub S, Münzel T, Klein T, Daiber A: Comparison of the Direct and Indirect Antioxidant Effects of DPP-4 Inhibitors: The AntiInflammatory and Vasodilatory Potential of Linagliptin. American Diabetes Association Scientific Sessions 2011 (ADA) 2011;71:981-PP.

53 Hocher B, Ziebig R, Altermann C, Krause R, Asmus G, Richter CM, Slowinski T, Sinha P, Neumayer HH: Different impact of biomarkers as mortality predictors among diabetic and nondiabetic patients undergoing hemodialysis. J Am Soc Nephrol 2003;14:2329-2337.

54 Chaykovska L, Tsuprrykov 0, Hocher B: Biomarkers for the Prediction of Mortality and Morbidity in Patients with Renal Replacement Therapy. Clin Lab 2011;57:455-467.

55 Alter ML, Kretschmer A, von Websky K, Tsuprykov O, Reichetzeder C, Simon A, Stasch JP, Hocher B: Early Urinary and Plasma Biomarkers for Experimental Diabetic Nephropathy. Clin Lab 2012;58:659-671.

56 Mitrovic V, Seferovic P, Dodic, D, Krotin M, Neskovic A, Dickstein K, Devoogd H, Böcker C, Ziegler D, Godes M, Najow R, Essers H, Verboom C, Hocher B: Cardio-Renal Effects of the A1 Adenosine Receptor Antagonist SLV320 in Patients with Heart Failure. Circulation: Heart Failure 2009;2:523-531.

57 Hocher B: Adenosine A1 Receptor Antagonists in Clinical Research and Development. Kidney Int 2010;78:438-445. 